\title{
EFFECT OF OPUNTIA ELATIOR ON CHOLESTEROL LEVEL ALTERATIONS INDUCED BY GAMMA RADIATION IN SWISS ALBINO MICE
}

\author{
KAVITA POONIAM, JAIMALA SHARMA*
}

Department of Zoology, Radiation Biology Laboratory, University of Rajasthan, Jaipur, Rajasthan, India. Email: jaimalauor@gmail.com Received: 07 January 2019, Revised and Accepted: 05 February 2019

\begin{abstract}
Objectives: Radiotherapy is deleterious to patient health by making the patient more susceptible to other diseases and often causes death by weakening the immune system and also affects cholesterol level. Based on these studies, it was moved toward the selection of Opuntia elatior as a herbal remedy for serum cholesterol level induced by gamma radiation.
\end{abstract}

Methods: The modulatory effect of 0 . elatior stem extract was studied in Swiss albino mice at dose, i.e., 6 Gy of gamma radiation in the presence (experimental) or absence (control) of 0 . elatior extract (OEE) $(10 \mathrm{mg} / \mathrm{kg}$ body weight) to observe in blood cholesterol level alterations. The animals were scarified and their blood was collected at days 1, 15, and 30 post-irradiation from heart puncture. Cholesterol level was estimated by the modified method of Roeschlau et al., 1974, using kit.

Results: The cholesterol level was found almost constant in the control group (without any treatment) and increased in gamma radiation-treated group and decreased in only plant extract-treated group, whereas radiation-induced increased level of cholesterol was reduced by plant extract treatment in experimental animals (in plant extract with radiation-treated group), a normal level was achieved by day 30 post-treatment. Hence, o. elatior is beneficial to control radiation-induced blood cholesterol level.

Conclusion: Radiation-induced side effects get lowered by herbal treatment and herbal products do not have their own side effects on body on their physical and chemical processes; thus, OEE is useful to manage blood cholesterol level as an edible part, it is easy to use as treatment and in my results OEE also support to maintain cholesterol level in serum of mice.

Keywords: Opuntia elatior, Gamma radiation, Cholesterol, Mice.

(C) 2019 The Authors. Published by Innovare Academic Sciences Pvt Ltd. This is an open access article under the CC BY license (http://creativecommons. org/licenses/by/4. 0/) DOI: http://dx.doi.org/10.22159/ajpcr.2019.v12i3.31294

\section{INTRODUCTION}

Gamma radiation, released through the nuclear detonation, is extremely energetic and is so pungent that a substantial part will pass through the human body without interaction. About $77 \%$ of the photons will interrelate with and lose energy to the atoms of the target tissue - gamma radiation penetrates through a medium with no interaction with electrons. Until they crash with elements of the atoms and liberate energetically charged particles that are ionizing [1].

High level of cholesterol or hypercholesterolemia is the root cause of cardiovascular diseases [2]. Cholesterol is directly related with ischemic stroke and has been observed to be indirectly related with a number of other consequences such as cancer and chronic respiratory disease [3].

Cholesterol in the body is useful as material used for hormones synthesis and membrane or cell wall formation. $83 \%$ of cholesterol is synthesized in the liver and the remaining comes from different types of food and beverages. However, extreme levels of cholesterol in the body can cause various diseases. In the present investigation, the effort of elevated cholesterol can be done by feeding high cholesterol mixed with propylthiouracil, so the condition of hypercholesterolemia is attained. Cholesterol high diets in can raise rats' blood cholesterol level. The use of goat fat and cooking oil along with the butter can lead to increased level of cholesterol in the blood as the material contains saturated fatty acids. Saturated fatty acids synthesize very low-density lipoprotein particles having elevated level of cholesterol [4]. Cholesterol plays a chief role in human heart health and is required in the body to insulate nerves, makes cell membranes, and synthesizes certain hormones, and it is an important lipid in some membranes [5]. According to the World Health Organization, about $50 \%$ of the heart attacks occur in individual with high level of cholesterol [6].
The cactus Opuntia (genus Opuntia, subfamily Opuntioideae, and family Cactaceae) is a xerophyte producing about 200-300 species and is mainly grown in arid ( $<250 \mathrm{~mm}$ annual precipitation) and semi-arid (250-450 mm annual precipitation) zones. Due to their tremendous genetic variability, Opuntia plants show a high ecological adaptivity and can, therefore, be encountered in places of virtually all climatic conditions: North, Central, and South America, the Mediterranean, North, Central and South Africa, the Middle East, Australia, and also in India $[7,8]$. Various studies have been reported on ethnopharmacological actions of Opuntia spp. such as antiviral [9], antihyperlipidemic, and hypercholesterolemic $[10,11]$. Based on these studies, we moved toward the selection of Opuntia elatior as an herbal remedy for serum cholesterol level induced by gamma radiation.

\section{METHODS}

Male Swiss albino mice (mus musculus norvegicus) 6-8 weeks old, weighing $25 \pm 2 \mathrm{~g}$ each from an inbred colony at the Department of Zoology, University of Rajasthan, Jaipur, were selected for the experiments. They were maintained under controlled conditions of temperature $37 \pm 5^{\circ} \mathrm{C}$ and kept in natural daylight and dark night cycles. Institutional animal ethics committee approval number of the Department of Zoology, University of Rajasthan, Jaipur, is CPCSEA registration no. 1678/Go/Re/S/12/CPCSEA dated 16.06.2017.

\section{Source of irradiation}

Animals were irradiated with cobalt teletherapy unit (ATC-C9) at Cancer Treatment Center, Radiotherapy Department, SMS Medical College and Hospital, Jaipur, Rajasthan, India. Unanesthetized animals were restrained in well-ventilated Perspex boxes $(30 \mathrm{~cm} \times 30 \mathrm{~cm} \times 5 \mathrm{~cm})$ and exposed whole body to gamma radiation with external $\mathrm{Co}^{60}$ teletherapy, SMS radiation unit with source surface distance of $80 \mathrm{~cm}$ to deliver the 
Table 1: Variation in cholesterol level of irradiated mouse with and without OEE (acetone) treatment (mg/dl)

\begin{tabular}{|c|c|c|c|}
\hline \multirow{2}{*}{$\begin{array}{l}\text { Experimental } \\
\text { Groups }\end{array}$} & \multicolumn{3}{|c|}{ Autopsy interval } \\
\hline & Day 1 & Day 15 & Day 30 \\
\hline Group 1 control (without any treatment) & $191.83 \pm 4.76$ & $196.5 \pm 4.83$ & $198.83 \pm 4.96$ \\
\hline Group 2 plant (extract only) & $197.5 \pm 4.90$ & $185 \pm 4.77$ & $178.33 \pm 4.62$ \\
\hline Group 3 plant $+R$ (extract $-10 \mathrm{mg} / \mathrm{kg}+6$ Gy radiation) & $190.66 \pm 4.75$ & $199.16 \pm 5.00$ & $195 \pm 4.79$ \\
\hline Group 4 radiation ( $6 \mathrm{~Gy}$ ) & $202.33 \pm 5.02$ & $241.5 \pm 5.15$ & $275.16 \pm 5.26$ \\
\hline
\end{tabular}

OEE: Opuntia elatior extract

Table 2: Two-way ANOVA

\begin{tabular}{|c|c|c|c|c|c|c|}
\hline Factor & Df & $\begin{array}{l}\text { Sum } \\
\text { square }\end{array}$ & $\begin{array}{l}\text { Mean } \\
\text { square }\end{array}$ & F value & $\operatorname{Pr}(>F)$ & Marks \\
\hline Treatment & 3 & 1777.95 & 585.11 & 121.12 & $<2.2 \mathrm{e}-78$ & $* *$ \\
\hline Day & 2 & 10.81 & 7.01 & 4.78 & 0.05111 & $* * *$ \\
\hline Treatment: Day & 6 & 256.37 & 38.65 & 24.441 & $1.15 E-32$ & $*$ \\
\hline
\end{tabular}

ANOVA: Analysis of variance

dose rate of $1.47 \mathrm{~Gy} / \mathrm{min}$. The dose rate was calibrated throughout the experimental period according to the decay table of $\mathrm{Co}^{60}$.

\section{Source of plant material}

The plants were collected from Botanical garden (Smriti van), Jaipur, Rajasthan, and voucher specimen was deposited in the Department of Botany, University of Rajasthan, for authentication (RUBL no. 211574).

\section{Preparation of plant extract}

O. elatior stem was peeled off, cut into pieces and shade dried and then powdered. Plant material was taken out and shade dried and then powdered. The extract of stem of $O$. elatior was prepared by extracting powder in ethanol and acetone separately at $68^{\circ} \mathrm{C}$ and $40^{\circ} \mathrm{C}$ in a Soxhlet apparatus for $36 \mathrm{~h}$ each. The animals were fed one extract at a time by gastric intubation with different dose rates according to the plan of experiments. Both ethanolic and acetone extracts were prepared at $10 \mathrm{mg} / \mathrm{kg}$ body weight (on the basis of survival assay)

\section{Design of experiment}

Adult, healthy, Swiss albino mice were used for the study. They were divided into four groups.

- Group I: Control mice without any treatment.

- Group II: $6 \mathrm{~Gy} \mathrm{Co}^{60}$ gamma radiations only.

- Group III: O. elatior extract (OEE) (10 mg/kg body weight only).

- Group IV: OEE (10 mg/kg body weight)+6 Gy $\mathrm{Co}^{60}$ gamma radiation

The animals were observed for changes in their behavior, body weight, and mortality (if, any). The animals will be sacrificed at suitable posttreatment intervals.

\section{Autopsy}

The animals from all the groups were sacrificed by cervical dislocation at 1,15 , and 30 days after irradiation. Six animals were sacrificed at each interval from every group and serum parameter cholesterol was studied.

\section{Estimation of cholesterol}

Cholesterol was estimated in serum using the kit supplied by Transasia Bio-Medicals Ltd., Baddi, Dist. Solan, HP, by the modified method of Roeschlau et al., 1974.

\section{RESULTS}

In the present study, alterations in various biochemical parameters level found to show a parallel pattern in all the groups. These were markedly suppressed in the 6 Gy irradiated animals and a normal value could not be achieved till the last autopsy interval (i.e., day 30). Prior administration of OEE enhanced the recovery in these parameters, and a normal value was registered by day $30^{\text {th }}$ post-treatment.
Cholesterol level when treated with OEE (in acetone solvent)

It was observed that in acetone extract the values in control group (without any treatment) showed almost similar pattern from day 1 to day 30. Further, in group treated with only plant extract, it was observed that the value decreased when registered by day $30^{\text {th }}$ post-treatment (197.5-178.3 mg/dl). In group treated with radiation along with plant extract, it was observed that the values increased registered by day $30^{\text {th }}$ post-treatment, but it was maximum in day $15^{\text {th }}(199.16 \mathrm{mg} / \mathrm{dl})$ that is almost equal to the control group. Finally, in group treated with only 6-8 Gy radiation, it was observed that the level constantly increased by day $30^{\text {th }}$ post-treatment from the day $1(202.33-275.16 \mathrm{mg} / \mathrm{dl})$ (Table 1).

Two-way analysis of variance (ANOVA) (two factors are day and treatment)

When ANOVA test was applied, it was observed that in acetone extract, treatment along with day was found to be less significant and individually day found highly significant and individually treatment was moderately significant. Results are in the following Table 2 .

\section{Cholesterol level when treated with OEE (in ethanol solvent)}

Further, in ethanolic extract, the values in control group (without any treatment) showed almost similar pattern from day 1 to 30. Further, in group treated with only plant extract, it was observed that the value increased when registered by day $30^{\text {th }}$ post-treatment $(181.5 .5-$ $198.33 \mathrm{mg} / \mathrm{dl}$ ). In group treated with radiation along with plant extract, it was observed that the values increased registered by day $30^{\text {th }}$ posttreatment, but it was maximum in day $30^{\text {th }}(184.5-192.83 \mathrm{mg} / \mathrm{dl})$ that values are equal to the control group. Finally, in group treated with only 6-8 Gy radiation, it was observed that the level constantly increased by day $30^{\text {th }}$ post-treatment from the day $1(222.83-262.00 \mathrm{mg} / \mathrm{dl})$ (Table 3).

\section{Two-way ANOVA}

When ANOVA test was applied, it was observed that in ethanol extract, treatment along with day was found to be less significant and individually day found highly significant and individually treatment was moderately significant. Results are in the following Table 4 .

\section{DISCUSSION}

Puttaswamy and Asna, 2016 [12], showed in vivo antihypercholesterolemic potency leaf extracts of Swietenia mahagoni. They reported that treatment with the plant samples decreased the cholesterol, alanine aminotransferase, high-density lipoprotein cholesterol (HDL-C), aspirate aminotransferase, and bilirubin levels and the results were dose dependent. It was reported that the plant possesses hypolipidemic potential and thus could be valuable in the treatment of hypercholesterolemic condition. Duangjai et al. [13] reported that different extracts of dietary plants have potent activity on lipid-lowering activity. They reported that the effects of some dietary plants including Azadirachta indica A. Juss. var. siamensis valeton (flowers), Bombax ceiba Linn. (pollen), Citrus hystrix DC (leaves), Polygonum odoratum Lour. (leaves), and Solanum torvum Sw. (fruits) on activity of pancreatic lipase, micellar cholesterol solubilization, and bile acids binding. Aqueous extract of $P$. odoratum reduced cholesterol level by $87 \%$. Ethanolic extract of $S$. torvum had the highest capacity to bind to taurodeoxycholic acid up to $97 \%$. Ethanolic and methanolic extracts 
Table 3: Variation in cholesterol level of irradiated mouse with and without OEE (ethanol) treatment (mg/dl)

\begin{tabular}{lllll}
\hline Experimental & & & \\
\cline { 4 - 5 } Groups & & Day $\mathbf{1}$ & Day 15 & Day $\mathbf{3 0}$ \\
\hline Group 1 control (without any treatment) & $185.83 \pm 1.45$ & $184.83 \pm 1.31$ & $186.83 \pm 1.56$ \\
Group 2 plant (extract only) & $181.5 \pm 1.31$ & $184.33 \pm 1.56$ & $198.33 \pm 2.02$ \\
Group 3 plant+R (extract-10 mg/kg+6 Gy radiation) & $184.5 \pm 2.02$ & $189.83 \pm 2.12$ & $192.83 \pm 2.17$ \\
Group 4 radiation (6 Gy) & $222.83 \pm 2.31$ & $256.33 \pm 2.56$ & $262.00 \pm 2.71$ \\
\hline
\end{tabular}

OEE: Opuntia elatior extract

Table 4: Two-way ANOVA

\begin{tabular}{lllllll}
\hline Factor & Df & $\begin{array}{l}\text { Sum } \\
\text { square }\end{array}$ & $\begin{array}{l}\text { Mean } \\
\text { square }\end{array}$ & F value & $\operatorname{Pr}(>\mathbf{F})$ & Marks \\
\hline Treatment & 3 & 1668.71 & 570.11 & 117.19 & $<2.2 \mathrm{e}-71$ & $* *$ \\
Day & 2 & 10.54 & 6.82 & 5.53 & 0.05099 & $* * *$ \\
Treatment: Day & 6 & 250.48 & 36.51 & 23.223 & $1.15 \mathrm{E}-29$ & $*$ \\
\hline \multicolumn{7}{l}{ ANOVA: Analysis of variance }
\end{tabular}

of $P$. odoratum bound to taurocholic acid $75 \%$ and glycodeoxycholic acid $40 \%$, respectively. These findings revealed the fact that lipid-lowering activity of these plants was eminent by different solvents.

Gururaja et al. [14] reported the evaluation of cholesterol-lowering activity of various extracts of Mangifera indica in albino Wistar rats. They reported that significant cholesterol-lowering activity was observed in methanol extract of $M$. indica leaves, at dose of $90 \mathrm{mg} / \mathrm{kg}$ body weight and their lethal dose was $<5000 \mathrm{mg} / \mathrm{kg}$ rat body. Iriflophenone $3-C-\beta$-D-glucoside and mangiferin were found to be in the range of $1.2-2.8 \% \mathrm{w} / \mathrm{w}$ and $3.9-4.6 \% \mathrm{w} / \mathrm{w}$, respectively, which along with $3 \beta$-taraxerol and other sterols which could be main source of phytochemicals responsible for cholesterol-lowering activity.

Lúcia et al., 2017 [15], reported the evaluation of phenolic compounds and lipid-lowering effect of Morus nigra leaves. They reported that hyperlipidemic rats treated with 100,200 , or $400 \mathrm{mg} / \mathrm{kg}$ of $\mathrm{MN}$ decreased serum cholesterol, triglycerides, and normalized lipoproteins. Furthermore, MN inhibited lipid peroxidation in liver, kidney, and brain of hyperlipidemic rats. They proved that $M$. nigra leaves are rich in polyphenols, mainly chlorogenic acid, which possesses normalized hyperlipidemic lowering activity.

Galati et al. [16] reported that the cholesterol, LDL, and triglyceride plasma levels were strongly reduced after 30 days of a daily administration (1 g/kg) of Opuntia ficus-indica L. Ennouri et al. [17] reported the effects of diets having adequate amount of cactus pear oil and seeds on serum and liver parameters, the outcomes indicated a significantly reduced blood cholesterol and LDL-C and increased HDL-C.

The acetone and ethanolic extract of experimental plant could increase the activity and mRNA expression level of CYP7A1 by promoting the cholesterol excretion of bile acid as its metabolite; meanwhile, it reduced the activity and mRNA expression level of HMG-CoA reductase to suppress the cholesterol biosynthesis [18].

Najib et al., 2018 [19], reported that cholesterol-lowering effects of extract from Garcinia daedalanthera in hyperlipidemic rats. They reported that $G$. daedalanthera extract significantly reduced the level of total cholesterol, total triglycerides, and LDL as compared to control group with an increasing level of serum HDL.

In another study investigated the protective effect of the ethanolic root extract of Operculina turpethum on serum lipid profile in male albino mice intoxicated with N-Nitrosodimethylamine [20].

In another significant study, Elaeocarpus ganitrus Roxb. extract treated rabbits showed significant protective effect by lowering the deposition of cholesterol and increasing the lumen size compared to cholesterolfed group [21].

\section{CONCLUSION}

Radiotherapy is deleterious to patient health by making the patient more susceptible to other diseases and often causes death by weakening the immune system. The ultimate goal of therapeutics is to increase the survival time and the quality of life of the patient. Recent research on herbal product has promising results to achieve this goal. Radiation-induced side effects get lowered by herbal treatment and herbal products do not have their own side effects on body on their physical and chemical processes; thus, OEE is useful to manage blood cholesterol level as an edible part, it is easy to use as treatment.

\section{ACKNOWLEDGMENTS}

The authors are thankful for Head, Department of Zoology, and CAS (Center for advanced studies), University of Rajasthan, for giving necessary facilities and also to UGC for giving me non-net fellowship.

\section{AUTHORS' CONTRIBUTIONS}

Kavita Poonia and Professor Jaimala Sharma both were contributed in research article by means of experimental work and write the research article.

\section{CONFLICTS OF INTEREST}

The authors had no conflicts of interest in the present investigation.

\section{REFERENCES}

1. Casserett AP. Radiation Biology. Englewood, New Jersey: Prentice Hall Inc.; 1968.

2. Salvamani S, Gunasekaran B, Shaharuddin NA, Ahmad SA, Shukor MY. Antiartherosclerotic effects of plant flavonoids. Biomed Res Int 2014;2014:480258.

3. Lawes CM, Hoorn SV, Law MR, Rodgers A. High cholesterol. In: Comparative Quantification of Health Risks. Geneva: Wealth Health Organization; 2003. p. 391-496.

4. Kusmiati FX, Dhewantara R. Cholesterol-Lowering Effect of Beta Glucan Extracted from Saccharomyces cerevisiae in Rats. Bandung, Indonesia: International Seminar on Pharmaceutics (ISP 2015); 2015.

5. Ma H. Cholesterol and human health. Nat Sci 2004;2:17-21.

6. Thomas J, Shentu TP, Singh DK. Cholesterol: Biosynthesis, functional diversity homeostasis and regulation by natural products. In: Biochemistry. London: Intech Open; 2016.

7. Nobel PS, Barbera G, Inglese P, Pimienta-Barrios E, editors. AgroEcology, Cultivation and Uses of Cactus Pear. Vol. 132. Rome: FAOPlant Production and Protection Paper; 1995. p. 36-48.

8. Yasen YM, Barringer SA, Splittstoesser WE. A note on the uses of Opuntia Spp. In central/North America. J Arid Environ 1996;32:347-53.

9. Ahmad A, Davies J, Randall S, Skinner GR. Antiviral properties of extract of Opuntia streptacantha. Antiviral Res 1996;30:75-85.

10. Gurbachan S, Felker P. Cactus: New world foods. Indian Hortic 1998;43:29-31.

11. Jones PJ, Raeini-Sarjaz M, Ntanios FY, Vanstone CA, Feng JY, Parsons WE, et al. Modulation of plasma lipid levels and cholesterol kinetics by phytosterol versus phytostanol esters. J Lipid Res 2000;41:697-705.

12. Puttaswamy NY, Asna U. In vivo antihypercholesterolemic potential of Swietenia mahagoni Leaf extract. Cholesterol 2016;2016:6. 
13. Duangjai A, Nanteetip L, Kanittaporn T, Anan O. Effects of extraction solvents of dietary plants on lipid lowering activity. J Med Plant Res 2016;10:538-45.

14. Gururaja GM, Mundkinajeddu D, Kumar AS, Dethe SM, Allan JJ, Agarwal A, et al. Evaluation of cholesterol-lowering activity of standardized extract of Mangifera indica in albino Wistar rats. Pharmacognosy Res 2017;9:21-6.

15. Lúcia BZ, Moreira YD, Dalmagro AP, Camargo A, Bini LA, Simionatto EL, et al. Evaluation of phenolic compounds and lipidlowering effect of Morus nigra Leaves extract An Acad Bras Ciên 2017;89:2805-15.

16. Galati EM, Mondello MR, Monforte MT, Galluzzo M, Miceli M, Tripodo MM. Effect of Opuntia ficus-indica (L.) Mill. Cladodes in the wound-healing process. J PACD 2003;1:16

17. Ennouri M, Hamadi F, Mohamed H, Evelyne B, Hamadi A, Najiba Z.
Effects of diet supplementation with cactus pear seeds and oil onserum and liver lipid parameters in rats. Food Chem 2007;101:248-53.

18. Jiang C, Wang Q, Wei Y, Yao N, Wu Z, Ma Y, et al. Cholesterol-lowering effects and potential mechanisms of different polar extracts from Cyclocarya paliurus Leave in hyperlipidemic mice. J Ethnopharmacol 2015;176:17-26.

19. Najib SZ, Wilzar F, Rani S, Berna E, Raymond T. Cholesterol-lowering effects of extract from Garcinia daedalanthera in hyperlipidemic rats. Pharmacogn J 2018;10:1125-8

20. Sharma V, Singh M. Alterations induced by N-nitrosodimethylamine and ethanolic root extract of Opurculina turpethumin in serum lipid profile of male Swiss albino mice. Asian J Pharm Clin Res 2012;3:69-73.

21. Jain KP, Sharma P, Joshi CS. Anti-atherosclerotic activity of Elaeocarpus ganitrus Roxb. In cholesterol fed rabbits. Asian J Pharm Clin Res 2017;10:80-4. 